\title{
Fear and (In)Security: The Canadian Government's Response to the Chilean Refugees
}

\author{
SUHA DIAB
}

\section{Abstract}

This article examines Canada's response to the Chilean refugee crisis in 1973. It explores the conditions that made the resettlement of Chilean refugees possible, despite the reluctance of the Canadian government to provide protection for them. The article focuses on the relation between the Canadian government's regulatory discourses and practices on the one hand, and the Canadian public's contestation of, and challenges to, such discourses and practices on the other.

The Chilean refugee crisis revealed that the Canadian refugee protection regime was subject to political ideology, with very little consideration given to the suffering of refugees constructed as a threat to Canadian social, political, and economic well-being. However, civil society played a pivotal role in compelling the government to take a stance toward the refugees, though the government was able to control refugee reception by being deliberately selective about which lives it would save. The visibility and the success of the Canadian public in advocating on behalf of the Chilean refugees demonstrated the potential of this emerging civil power to affect refugee policies and practices while also revealing its limitations.

\section{Résumé}

Cet article examine la réponse du Canada à la crise des réfugiés chiliens de 1973. Il explore les conditions sous lesquelles la réinstallation des réfugiés chiliens était rendue possible malgré la réticence de la part du gouvernement canadien à offrir une protection pour ces réfugiés. L'article se concentre en particulier sur le lien entre les discours et pratiques règlementaires du gouvernement canadien d'un côté, et de l'autre la contestation ainsi que l'opposition envers ces discours et pratiques de la part de la société civile canadienne.

La crise des réfugiés chiliens avait démontré que le système canadien de protection des réfugiés était sous l'emprise de l'idéologie politique, donnant très peu de considération à la souffrance humaine des réfugiés, qui étaient présentés comme une menace au bien-être social, politique et économique du Canada. Néanmoins, la société civile avait joué un rôle déterminant en incitant le gouvernement à adopter une position envers les réfugiés, bien que celui-ci avait pu maintenir son emprise sur l'accueil des réfugiés en sélectionnant d'une façon délibérée lesquels il voulait sauver. La visibilité ainsi que le succès de la société civile canadienne dans son intervention en faveur des réfugiés chiliens avait mis en évidence le potentiel de cette force civile émergente, mais en même temps avait aussi souligné ses limitations.

\section{Introduction and Review of the Literature}

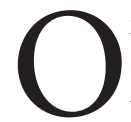

n 11 September 1973, General Augusto Pinochet, supported by the American administration and the Central Intelligence Agency (CIA), led a successful coup d'état against the democratically elected communist government of Salvador Allende in Chile. The first few months following the coup were the most critical, because Pinochet's military and security forces used the 
most lethal forms of violence in order to eliminate "the cancerous tumor" of opposition. ${ }^{1}$ Thousands were killed or tortured by virtue of their political affiliation with Allende.

With Amnesty International's revelation of these atrocities to the international community in late 1973, Pinochet's governing style was put under scrutiny, leading him to adopt a more calculated and controlled display of violence. While there is no credible figure on the number of civilians killed during this period, Amnesty International estimated that between 11 September and the end of December 1973, 5,000 to 30,000 people lost their lives in detention centres, or were simply killed in the open streets.

Chileans and other nationals whose lives were in immediate danger sought sanctuary in foreign embassies in Santiago, since they were considered safer than the camps established by the United Nations High Commissioner for Refugees (UNHCR). ${ }^{2}$ Unlike the many embassies in Santiago that granted diplomatic asylum to refugees, the Canadian embassy was very selective and reluctant to allow people in. This response reflected the Canadian government's general attitude toward the Chilean refugees, which was characterized by apprehension and suspicion.

With the exception of providing protection to fifty young and educated individuals in its embassy, the Canadian government avoided any meaningful action to save the lives of people in danger in the first four months following the coup. The unique treatment of Chilean refugees brings to the fore the contradictions inherent in Canada's perceived humanitarian tradition of refugee protection, especially considering the swift Canadian response to the Ugandan-Asian refugee crisis the year before. In less than three months after the expulsion order imposed by Amin in August 1972, the Canadian government resettled more than 6,000 Asians.

Studies have examined the Canadian response to the Chilean refugees. For instance, Dirks (1979), Troper (1993), and Whitaker (1987) contend that anti-communist ideology (informed by Canada's economic interests) was the driving force behind the delays and rejections of many of the applications submitted by Chileans for resettlement. ${ }^{3}$ Duggan (1994), Knowles (2007), and Simmons (1993) assert that the government's decision to intervene in the Chilean crisis was due to a defiant public that challenged the resettlement scheme. 4 These studies provide useful information on the factors influencing the Canadian government's approach in Chile. However, historical accounts tend to over-simplify the complexity of this response, or provide very little insight into how government policies and practices were implemented to achieve its goal in limiting the number of Chileans entering Canada.

The only work written in English that pays close attention to, and offers a comprehensive examination of, the response of the Canadian government in Chile is Francis Peddie's Young, Well-Educated, and Adaptable, published late last year. Peddie presents a more complex and multilayered analysis of Canada's response. ${ }^{5}$ He points to the multiple forces at work that influenced it, including Canada's economic and national interests, relations with the United States, the Canadian ambassador's attitudes toward Allende and Pinochet, and the instrumental role played by Canadian civil society, especially church groups. Ultimately, Peddie asserts that the reaction of the Canadian government was "shaped [more] by ideological concerns and economic prerogatives," and less by ostensible humanitarian concerns. ${ }^{6}$

Peddie presents a full account of the different forces that affected the Canadian government's response, and thus provides a pivotal contribution to this area of study. Unfortunately, he provides very little analysis of how these different forces came together to control the entry of Chilean refugees to Canada. This deficiency might be due to the fact that his study, as he points out, is less concerned with "state actors and structural factors" than with how Chileans dealt with "the issues of admission and settlement."7 Peddie also places too much emphasis on Canada's relation with the United States as a determining factor of its response.

My research, which involved reading thousands of documents and exchanges between government officials, has found very little evidence to support this claim. Canadian government officials formulated and rationalized their response to the refugee crisis in Chile on many occasions, but relations between Canada and the United States did not appear to play any significant role. Similarly, Canada's decision to recognize the junta, which arguably had farreaching implications, paid very little attention to CanadaU.S. relations. Once the safety of Canadians in Chile was established, the decision to recognize the junta was based mainly on Canada's economic interests, while taking into account decisions made by other countries, especially in the Commonwealth and Latin America. This was clearly demonstrated in a memorandum to the minister of external affairs and the prime minister in late September 1973:

Re-establishing de jure diplomatic relations with Chile would evidently prove most helpful in negotiating, probably multilaterally and at the higher official level, a solution to this pressing matter. From a commercial point of view, recognition is becoming an urgent requirement. Before the coup, the EDC had insured the sale of six Twin Otters to the Chilean national airline LAN. These airplanes are now being assembled and a contract is to be signed with LAN. ITAC has informed us that the Chileans badly need these airplanes and will arrange for the signature of the contract immediately following the recognition ... Further withholding recognition ... could well start complicating our bilateral 
relations. The two basic conditions for extending recognition have been fulfilled: as already mentioned the Junta firmly controls the national territory and it has pledged that it will honour Chile's international obligations which includes the debt to the members of the Paris Club. The military can also claim that their regime is enjoying reasonable support from large, moderate sectors of the population as the only alternative to chaos. Up to this date some 35 countries have recognized the Junta. ${ }^{8}$

The absence of any American influence is not surprising. Unlike his predecessors, Trudeau believed that Canada needed to focus less on pursuing ideological alliances with the United States, and more on developing its international economic interests. ${ }^{9}$ This move coincided with the relative decline of U.S. hegemony in some parts of the world, as well as Trudeau's uneasy relationship with the U.S. administration during Nixon's term in office. ${ }^{10}$ Between 1968 and 1976 Canada showed leadership and independence on the world stage by seeking closer economic ties with countries in the Commonwealth, Asia, Africa, Europe, Latin America, and the Caribbean, including communist countries, while distancing itself from the United States and its ideological policies.

Focusing on the first four months of the crisis, the study is concerned both with the forces and relations of power that made it possible for the Canadian government to intervene and resettle Chileans, and with how these forces and relations were applied and assembled through legislation, policies, institutions, discourses, and other practices to create certain effects.

The first part discusses my theoretical and methodological approach, which relies on the work of Michel Foucault, Gilles Deleuze, and Félix Guattari on assemblage/ apparatus, as well as on Tania Li's analysis of practices of assemblage. The second part applies the practices proposed by Li to examine how the Canadian government assembled its response to the Chilean refugee crisis. The article concludes with a summary of its main contributions and potential future work in the area.

The article argues that "cultural racism," along with coveted trade agreements and the desire to halt communist and Quebec separatist contamination-in short, Canada's political and economic interests-initially overshadowed the human suffering inflicted by the Pinochet regime. Cultural racism, as Balibar points out, is employed to exclude cultures that do not possess Western liberal values, such as “'individual' enterprise, social and political individualism."11

In a context of growing public protests, the Canadian government had to seriously commit to an action plan for resettlement. It justified this intervention on the grounds of security and humanitarian concerns. As a result of the screening processes of the Royal Canadian Mounted Police
(RCMP), which sought to exclude individuals with communist or Quebec separatist leanings, and health and immigration officials who implemented Canada's point system, a well-educated, young, and highly desirable immigrant group of Chileans was selected. ${ }^{12}$ That being said, Canada's assembled response was not straightforward, as it reflected contradictions and tensions between the stakeholders involved.

\section{Theoretical Perspective and Methodology}

In his influential Confession of the Flesh, Foucault elaborates on the concept of dispositive/apparatus, noting that it refers to the system of relations (of power) established between "a thoroughly heterogeneous ensemble consisting of discourses, institutions, architectural forms, regulatory decisions, laws, administrative measures, scientific statements, philosophical, moral and philanthropic propositions-in short, the said as much as the unsaid. Such are the elements of the Apparatus."13 Through these complex relations of power (whether repressive and negative, or positive and productive), the apparatus shapes conduct.

Foucault adds that the apparatus involves different connections and reconfigurations between heterogeneous elements. "[A] particular discourse can figure at one time as the programme of an institution," Foucault notes, "and at another it can function as a means of justifying or masking a practice which itself remains silent, or as a secondary re-interpretation of this practice, opening out for it a new field of rationality." ${ }^{4}$ It is an assemblage of different ways in which power is practised: "a formation which had as its major function at a given historical moment that of responding to an urgent need ... [that] has a dominant strategic function."15

Deleuze and Guattari build on Foucault's work by introducing the concept of assemblage, agencement, which denotes "a contingent ensemble of diverse practices and things that is divided along the axes of territoriality and deterritorialisation. Furthermore, particular alignments of technical and administrative practices extract and give intelligibility to new spaces by decoding and encoding milieus. In short, particular assemblages of technology and politics not only create their spaces, but also give diverse values to the practices and actors thus connected to each other." Deleuze and Guattari call any multiplicity of interconnected techniques and actors "a continuous self-vibrating" plateau. ${ }^{16}$

Assemblage is concerned with rhizomatic expansion as well as disaggregated and heterogeneous elements. ${ }^{17}$ Slater argues that assemblage has the same effect as apparatus, but without Foucault's preoccupation with the notion of order. ${ }^{18}$

The concepts of assemblage have been utilized in studies to explore a whole range of issues. Slater, and Haggerty and 
Ericson employ the terms mobility assemblage and surveillant assemblage respectively to explore issues of surveillance. Haggerty and Ericson argue that the surveillant assemblage ultimately aims to achieve certain finalities, whether economic profit, social control, and/or managing behaviour. ${ }^{19}$ Yet Slater insists that the surveillance and management of circulation is not driven by "an internal logic," but rather expands "to fit the space available." 20 The inconsistency in these bodies of work on assemblage relates to the philosophical tradition underlying the work. Whereas Haggerty and Ericson seem to adopt it in relation to Foucault's concept of apparatus, Slater applies a strict Deleuzian reading.

With that said, Legg argues that it is possible to bring these two terms together. While he acknowledges that Deleuze uses the term to highlight dis-order, he argues that he "also portrayed assemblages as leading to order, striation, re-territorialisation, long-term effects and scaling as much as to dis-order, smoothing, de-territorialisation, short-term effects and de-scaling." ${ }^{21}$ In this study, I follow Legg's proposition of a shared understanding of apparatus/assemblage. I rely on Tania Li's methodological and theoretical framework adopted in her Practices of Assemblage and Community Forest Management, where she operationalizes the use of assemblage. She identifies six practices that are generic in any assemblage-forging alignments, rendering technology, authorizing knowledge, managing failures, engaging in anti-politics, and reassembling-thus blurring the philosophical difference between apparatus and assemblage. I loosely employ these generic attributes to shed light on "the way in which heterogeneous elements including 'discourses, institutions, architectural forms, philosophical, moral and philanthropic propositions' are assembled to address an "urgent need' and invested with strategic purpose."22

The appeal of the concept of assemblage, as applied by $\mathrm{Li}$, lies in its practical yet complex analytical contribution. It problematizes the Canadian government's response to the Chilean refugee crisis by highlighting connections, contestations, and tensions between the stakeholders who forged the refugee resettlement, including state actors, Canadian civil society, non-governmental organizations (NGOs), and Chilean refugees. It provides insight into how the Chilean refugees and their resettlement were problematized - that is, diagnosed, framed, and disrupted in response to seen and unforeseen circumstances. Finally, it places government intervention (or the lack of it) within a political, economic, historical, and social context that produced "the actual and the possible." 23 It draws attention to how different forces came together at a particular conjuncture "only to disperse or realign." 24 Drawing on Li's proposed practices, I will consider the unique integration of the forces and relations of power at particular conjunctures in order to reveal the conditions that made the resettlement of the Chilean refugees possible.

In her Along the Archival Grain, Stoler maintains that engaging with the "archive as subject" rather than "source" opens up new avenues for analyzing the past where facts are produced by states in order to contain the reality of governance. ${ }^{25}$ My research project, which relies for the most part on archival material, examines the contradictions and silences in "factual" narratives, examining the conditions of production.

I accessed archival records on Chile at Library and Archives Canada (LAC), the Citizenship and Immigration Canada Library, and Carleton University library. The records, which date from the late 1970 s to early 1975 , include letters, memorandums, and reports written by the Canadian ambassador in Santiago, ministers and their deputies, the prime minister, the Cabinet, and the bureaucracy relating to the crisis in Chile. Further, I surveyed reports written by human rights and advocacy groups, including church groups, university professors, unions, and other ordinary Canadians appealing for the resettlement of the Chilean refugees. I also scanned news articles and editorials appearing in Canadian media outlets and used secondary sources on the Chilean refugee crisis.

In reading these documents, I focused on how and why Chilean refugees were securitized and/or humanized. I paid particular attention to the ways different domestic and global forces and events, such as the Cold War, American policy in Latin America, U.S.-Canada relations, the Quebec Crisis, the rise of civil rights movements in Canada and the United States, and Canada's previous response to refugee crises abroad might have shaped this response. I also attended to how this response was implemented and presented publicly and privately; that is, what the government said, how it acted, and what rules it imposed in response to this refugee crisis. The data were analyzed by applying Li's practices of assemblage.

\section{Discussion: Assembling the Government Response to the Chilean Refugee Crisis}

The response of the Canadian government to the Chilean refugee crisis is an assemblage that emerged out of the struggle between actors to achieve their objectives at a particular conjuncture. These actors included government officials, such as the Canadian ambassador in Chile, the minister of immigration and the minister of foreign affairs and other advisors from the department, the RCMP, Immigration and Health and Foreign Affairs, the UNHCR, the New Democratic Party (NDP), Canadian churches, and other civil society groups. Each actor aspired to maintain or increase its power over Canada's economic and political 
interests in Chile, preserving Canadian unity, ensuring the safety and security of Canadians domestically and abroad, controlling entry to Canada by selecting immigrants who would contribute to its political economy, and resettling Chileans in need of protection.

This response was ultimately a struggle between authorities' will to preserve the security apparatus and their desire to manage the aspirations of (free) citizens to uphold Canada's humanitarian tradition. Drawing on the practices identified by Li, the following four sections map out and analyze how these elements were brought together, high lighting moments of fracture, contradiction, and failure.

\section{Forging Alignments}

Forging alignments, according to Li, refers to the ways in which certain links are assembled to meet the objectives of those "who aspire to govern conduct" and "those whose conduct is to be conducted." 26 For Rose, these links are essential to the logic of liberal government, because they simultaneously reinforce the "autonomy of certain 'private' zones" and shape the conduct and "aspirations of free [autonomous] citizens." The autonomy of citizens, Rose points out, needs to "be allied with, and aligned with, such objectives as economic success, national population policy, conceptions of desirability of education and training and the like." ${ }^{27}$ That said, the work of forging alignments is also fragile, because it requires the negotiation of conflicting demands and interests. ${ }^{28}$

Forging alignments between actors in this assemblage was not straightforward, as it underlined different aspirations, values, and interests. Upon winning the federal election in 1968, Pierre Elliot Trudeau clarified that promoting national unity and Canadian economic interests abroad were his priorities. ${ }^{29}$ Domestically, Trudeau was concerned with Quebec's bid for independence, and with the growing prominence of the Front de libération du Québec (FLQ), which he saw as a terrorist group in part because of its involvement in the kidnapping of the British trade commissioner and the Quebec minister of labour in October 1970. It was claimed that the FLQ had been trained by antiimperialist movements in Latin America, whose "terrorist" tactics it had ostensibly used. ${ }^{30}$

To deal with the challenge of the FLQ, the government entrusted the RCMP with monitoring and controlling the activities of Quebeckers domestically and abroad. The RCMP also worked closely with Canadian immigration officials abroad to ensure the selection of individuals who contributed to Canada's Western liberal democratic values and the exclusion of others who were perceived as threatening those values.

Meanwhile, Quebec had well-established ties to Latin America. These ties were largely due to surplus Catholic priests who left during the Quiet Revolution for the predominately Catholic Latin America, which was experiencing a shortage of priests. Quebec perceived the presence of these priests as "a reinforcement of its 'special status' as a 'Latin' region of North America," and as "projecting the French reality in the Americas." ${ }^{11}$ Further, the Comite de Solidarité Québec-Chili, which was established shortly after the coup, made an immediate connection between the struggle of Quebeckers and the Chilean people: "In Québec, we had the War Measures Act and Bill 19, followed by the imprisonment of union leaders. Our 'democracy' cites national security and essential services as its justification; the military junta invokes security and national reconstruction." 32 This connection, along with the religious and cultural association with Chile, was the basis for the "quick mobilization in Québec."33

While this connection forged an alignment between Quebec and refugees from Chile, it also presented fracture lines. It threatened the Canadian government's aspiration to control Quebec's independence, and to allow the entry of individuals who were perceived as unfit for its Western liberal values. The alignment of Chilean refugees in need of protection and the Canadian government was further compounded by Canada's economic interests. These interests were managed by Mitchell Sharp, the minister of external affairs, who "emerged as a business-like manager of Canadian foreign policy." 34 Sharp conceived relations between Latin America and Canada as centred solely on economic interests and ensured that diplomatic postings abroad reflected this priority. 35

As Chileans and other nationals were fleeing Pinochet's violence and persecution, the Canadian government was negotiating trade and debt-reduction agreements with Pinochet. Once Pinochet seized power, imports from and exports to Chile increased substantially. In fact, the Canadian Export Development Corporation Department even sold Pinochet military equipment, including de Havilland aircraft, for $\$ 5$ million. ${ }^{36}$ Canada also endorsed the InterAmerican Development Bank (IADB) in granting the Chilean government loans totalling $\$ 100$ million, when Nordic countries refused to approve similar loans. ${ }^{37}$

Canadian economic interests in Chile were preserved and coordinated by the Canadian ambassador to Chile, Andrew Ross, who later emerged in the eyes of the Canadian public as the architect of the government's decision not to immediately intervene in protecting Chileans, and hence as an unsympathetic figure. Ross's dislike of Allende and his supporters, and his unequivocal support of Pinochet, was clearly articulated in his letters to the office of External Affairs in Ottawa. These exchanges revealed that the Canadian government was less concerned with the fate 
of Chileans, and more with the economic interests that might be capitalized on by Chile's change of government..$^{8}$ Ross expressed his resistance to any resettlement initiative due to the Chilean refugees' "culture," and its implications for Canadian commercial relations with Chile. "It would be most unwise to officially deliver homilies on [the] virtues of democracy as we practice it under entirely different conditions ... [and] counter-productive in terms of our political and commercial relations with Chile," he wrote in a Telex to External Affairs. 39

That said, the ambassador delivered what the government wanted to hear. Ross was diligent in briefing the minister's office on the situation in Chile, including his intention to prevent people from entering the embassy. ${ }^{40}$ With the encouragement of the Ministry of External Affairs, Ross sought to secure Canadian interests, which incidentally involved closing the door on people in immediate need of protection.

The conditions that made it possible for Canada to maintain its economic interests in Chile, and to exclude Chileans from protection, were slowly being fractured, allowing more space for public discontent. Indefatigable priests and bishops who witnessed first-hand the atrocities committed by Pinochet during their service in Chile contested the narrative of the government. Upon returning to Canada, they exposed these atrocities, along with the Canadian government's attitudes toward Pinochet, to the broader Canadian public. ${ }^{41}$ These clergymen, whose churches had been involved in government resettlement schemes since the Second World War, also put intense pressure on the government to resettle Chileans. The testimonies of these clergymen were echoed and supported by Amnesty International's report published in December 1973, which exposed state repression, torture, and human rights violations.

Other segments of Canadian society, including unions, university professors and students, and human rights groups rallied behind church groups, thus forging a stronger alignment with the Chilean refugees. ${ }^{42}$ This organic mobilization was due not only to the intervention of church groups, but also to the socio-political environment in which the Chilean crisis occurred. Between the late 1960 s and early 1970s, anti-American sentiments were rising among Canadians who disapproved of the Vietnam War, anti-communist ideology, and U.S. imperialist policy in Latin America. Mainstream civil society groups, including academics and church groups, contested the designation of certain groups who resisted colonial and imperial powers as terrorists, when other European refugees from communist regimes were perceived as freedom fighters.

The NDP, which held the balance of power in the minority Liberal government, was also very critical of the government's response to the crisis in Chile. It was vocally opposed to the recognition of the junta. It also urged the government to recognize diplomatic asylum and expedite the resettlement of Chileans. Most notably, the NDP leaked confidential cables, written by the Canadian ambassador in Chile to the Department of External Affairs, to the media. In these cables Ross described the Chileans as "riff raff" and noted that Pinochet brought an end to the "political madness" of the Allende government. 43

The leaks seriously damaged the government's credibility on the issue of the Chilean refugees, exposing official indifference to human suffering. The minister of external affairs did not explicitly defend his ambassador's actions, which inadvertently implied that the ambassador acted alone. The government's decision to finally intervene aimed to address its failure to properly manage knowledge and accurately assess the growing role of civil society in refugee protection issues.

\section{Managing Failures and Contradictions: Framing the Arena of Intervention}

$\mathrm{Li}$ addresses managing failures to the "outcome of rectifiable deficiencies" and the means through which compromises are devised. Contradictions in this case are viewed as "superficial," but not "fundamental." Framing is particularly important in managing "the unruly array of forces and relations," and in producing an intervention with "optimal arrangements." The technical solutions authorized by the government to deal with failures "present simplified narratives of problem/solution that gloss over tensions to make the assemblage appear far more coherent than it is." 44

Despite the appeal of Canadian church groups in the first few weeks of the crisis, government authorities limited the number of refugees entering the embassy and publicly downplayed the crisis in Chile. Based on instructions from External Affairs, the ambassador in Chile applied a narrow interpretation of protection. Individuals were allowed entry into the embassy if they proved that their lives were in immediate and imminent danger. 45 The government was also careful in the ways it framed the refugee crisis in Chile to the public. A memorandum written to the minister of external affairs on 12 October 1973 suggested that the minister should refrain from using the term refugee or refuge, further explaining,

It has become evident that the use of the term "refugee" may cause problems because of the potential abuse by persons seeking admission to Canada of claims to refugee status ... It would be most desirable in statement or in response to questions in the House, therefore, to avoid use of the word "refugee" entirely when referring to the Chilean situation or to the fifteen who have 
come forward to Canada. "Persons affected by the coupe," "those who took shelter," or some such phrase, would be an acceptable alternative. It might also be helpful to refer to "shelter" rather than "refuge."46

With growing public pressure and the exposure of the diplomatic cables, the Canadian government had very little choice but to reveal an action plan. To deal with this crisis of confidence, the government deployed a senior official from External Affairs, and another from the Department of Manpower and Immigration, on 19 November 1973 to Chile and neighbouring countries to assess the needs of refugees. In reporting back to the government, the officials pointed out that the fear of death and detention was still high. They advised the government to adopt a humanitarian approach to meet the needs of vulnerable individuals. This approach, they pointed out, needed to take into account public expectations in light of Canada's humanitarian tradition, the risks and inconveniences that refugees might pose to Canadians and Canada's interests, and implications for immigration policy. 47

Stevenson notes that the report was "crucial in forging a new program to bring Chileans to Canada." 48 By adopting this program, the government opted to revise its attitudes to meet new conditions of formation that took into account the desires and aspirations of civil society. Nonetheless, the government imposed new technologies of control through rigid screening, which was presented as essential in eliminating threats to Canadians and their democratic institutions. That said, selection became the "site of contestation" among stakeholders.

The first special measure adopted by the government targeted the resettlement of 300 to 1,000 refugees and "oppressed persons," both Chilean and non-Chilean, inside and outside of Chile, by February 1974. The second offered a special protection operation to be completed by 2 January 1974 for a single group of fifty Chileans who were at risk of harm or long-term detention, and were not registered with the UNHCR. This humanitarian intervention, noted Andras, aimed to "meet genuine feeling and deep humanitarian concern which continue to be conveyed ... by many Canadians and in particular church leaders." He also pointed out that the provisions adopted toward the Chilean refugees would be "comparable to those applied to the past movements to Canada." 49

Unlike the Ugandan-Asian resettlement the previous year, which involved no security screenings, the instructions from the minister's office insisted that Chileans and other nationals considered for resettlement undergo strict security screenings to exclude "known terrorists and persons with serious non-political criminal records."50
"Chilean refugees seeking landed immigrant status in Canada," added the minister in a telephone interview with the Toronto Star on 3 December 1973, "will be refused admission if their political beliefs lead to violence."51

The framing of the Chilean refugees as endangering the well-being of Canadians and their institutions was essential in justifying exclusionary practices. In a letter to the prime minister justifying the rigid security screening, Andras emphasized his responsibility to protect Canadians: "The decision to admit people to our embassy would not be an immigration decision but any problems that subsequently result would certainly become my responsibility ... [P]art of that responsibility is the protection of residents of Canada from the admission of persons who represent serious threats to security and order." 52

Andras also reiterated the public danger posed by Chileans: "[There will be] hell to pay in this country [over the decision to admit Chileans to Canada]," he declared. "Yes, there are Marxists among them, I suppose ... We think we've screened out anybody who really wants to import violent overthrow of the Canadian government."53

The framing of the Chileans as dangerous justified the formulation and adoption of rigid security and immigration screenings. Thus once the Canadian ambassador was no longer credible in the public eye, the power to decide matters of life and death was handed over to the minister of immigration, the RCMP, and immigration and health officials. The legislation implemented by the minister of immigration, which was framed in terms of humanitarian concern with suffering and loss of life, aimed, along with immigration and health officials' screening processes, to select refugees who demonstrated an ability to integrate into Canadian society and the labour market, and not to burden Canada's welfare system or endanger public health. The Chilean refugee crisis became a technical, "anti-political" issue subject to immigration and security screenings.

Anti-Political Practices and Authorized Knowledge I use the term anti-political in Li's sense. She uses it to refer to the ways in which political questions become a matter of technique when dismissing or limiting debate on "how and what to govern and the distributive effects of particular arrangements by reference to expertise." The government's assembled humanitarian response, which involved the discretionary power of the minister along with a series of legislative and other practices, was presented as having the neutral objective of remedying human suffering. The screening processes of immigration and health officials, and the RCMP, were treated as a technical means to achieve this humanitarian goal while protecting the safety and security of Canadians. The success of this assemblage was 
determined by the authorization of knowledge, which for $\mathrm{Li}$ refers to "specifying the requisite body of knowledge; confirming enabling assumptions; containing critique." 54

Institutions are carriers of ideas and collective memories. 55 These ideas and memories are essential in understanding RCMP activity in Chile. In 1946, Canada's prime minister, Mackenzie King, created the RCMP with the sole mission of preventing communist infiltration into Canada. ${ }^{6}$ By the early 1970 s the RCMP was also charged with closely monitoring FLQ activities. The RCMP enjoyed great discretionary power and autonomy, and operated with considerable secrecy and scant accountability to the public. It was only in the early 1980 s, following the publication of the McDonald report, which investigated the RCMP's alleged involvement in illegal activities in Canada, that the RCMP's power was scrutinized.

While RCMP activities in Canada were exposed and eventually scrutinized, the extent of its activities abroad, which largely affected refugees, was never explored. Where refugees were concerned, the RCMP had full power over life. "For all intents and purposes," Agamben notes, "the normal rule of law is suspended and ... the fact that atrocities may or may not be committed does not depend on law but rather on the civility and ethical sense of the police that act temporarily as sovereign." 57

The RCMP was in full command of the security screenings of Chileans. It based its decisions on information from foreign intelligence, including the CIA, which incidentally assisted Pinochet in toppling the Allende regime. ${ }^{58}$ From the RCMP's perspective, the Chilean refugees were exactly the kind of immigrants that Canada needed to avoid. They were the most dangerous, as they represented the combined threat of communism and Quebec separatism. They were also associated with and supported by unions, academics, students, and progressive church groups in Quebec-the same groups that the RCMP had been monitoring in Canada out of fear of communist or FLQ infiltration. Given the mission and history of the RCMP, it is not surprising that the security screenings of the RCMP were the primary reason for the delays in processing the applications of the Chilean refugees, and the high rate of rejection. Among the 2,321 applications received by 4 January 1974, only 109 persons received immigration visas. 59

Despite the relaxed immigration criteria, Chileans still needed to demonstrate their ability to integrate into Canadian society in accordance with Canada's point system. The point system was adopted in 1967 to deal with the growing need for technical and industrial economies, and to officially eliminate previous racist rules that gave preference to European immigrants. This system, which remains the primary instrument for immigrant selection, decided immigrant selection on the basis of family ties, language acquisition, job skills, and education. Individuals were awarded a maximum number of points in each category. The system, which was adopted in the name of liberalism, justice, diversity, and equal opportunity, along with the administrative measures dealing with immigration offices abroad, micromanaged immigrants' entry to Canada.

Although the adoption of the point system was framed as a departure from previous racist policy, it demonstrated a new form of racism. It employed "cultural racism" where certain cultures that promoted Western liberal and individualistic values were welcomed in Canada. "The cultures supposed implicitly superior," notes Balibar, "are said to be the cultures whose 'spirit of community' is constituted by individualism." 60 As a result of the (somewhat relaxed) point system, the resettled Chileans who came to Canada were, as Andras commented, "young, well-educated and adaptable people who, with a little help, can be expected to add their contribution to the richness and variety of Canada." 61

Whereas the RCMP sought to eradicate communist and Quebec separatist threats, immigration and health officials were eager to screen and select for adaptable immigrants who would contribute to Canada's economy and whose lives were at risk. These goals were not fully compatible with each other. The RCMP's concerns with securing Canada's political survival at times contradicted immigration officials' humanitarian mission. Many Chileans who urgently needed immigration officials' humanitarian intervention were exactly the refugees that the RCMP was screening out. This inherit contradiction was fundamental in glossing over the Canadian government's aim of controlling the entry of Chileans.

\section{Reassembling}

Reassembling involves "grafting on new elements and reworking old ones" by employing new discourses to old ones and changing meanings and key terms. ${ }^{62}$ The assemblage of power created to control the Chilean refugees in this early period influenced the Canadian government's responses and attitudes to other refugee crises abroad.

This crisis revealed the emergence of civil society as a powerful actor in challenging the practices of the government in refugee crises abroad. Prior to this, civil society had very little influence on immigration and refugee policies and practices. ${ }^{63}$ Hanff asserts that the resettlement of the Chilean refugees marks a fundamental shift in the role that civil society plays in crucial foreign policy issues: "The Canadian government took this decision, not because its stability was threatened, but rather because the high profile of the activists and the visibility of the pressure threatened an image that Canadians and non-Canadians seem to have 
about Canada. At its narrowest, this image could be defined in terms of Canada's so-called refuge-thinking tradition. In its broadest context, it is defined in terms of Canada's internationally responsible attitude." 64

For the first time, governing authorities needed to actively engage with civil society in order to manage expectations, especially when refugees did not conform to the governing authorities' desires. The growing role of civil society was reflected, for example, in the decision of the minister of manpower and immigration to conduct coast-to-coast public consultations on immigration issues in 1973. The assembled "partnership" between civil society groups and the government was framed as a humanitarian and nonpolitical response. Since then, refugee reception has been presented as a negotiated compromise, not as reflecting the sole vision of the government.

Further, in light of the Chilean and Ugandan-Asian resettlement, the government incorporated the "designated classes" provision into the 1976 Immigration Act. Canadian policy-makers believed that the Refugee Convention definition was not encompassing enough to include individuals who did not cross internationally recognized boundaries, and whose "collective situation placed them in a de facto refugee situation." 65 Under this category, persons who are able to successfully establish themselves in Canada are issued landed immigrant visas. "The sponsorship allocation statistics," Hathaway writes, "give the impression of a larger Canadian contribution to the relief of the international refugee burden than is actually the case." 66 The number of "refugees" sponsored under this category is included in the annual refugee quota allocated by the government when many are not refugees at all.

Moreover, while the government insisted that this provision aimed to provide flexible tools in responding to humanitarian needs, Hathaway points out that this designated class reflects not only economic but also political considerations. ${ }^{67}$ This issue was raised in a motion to amend the admissibility section 19(e) of the 1976 Immigration Act. The amendment sought to ensure that there is "no distinction among refugees, fleeing rightist or leftist persecution." 68 The minister of employment and immigration rejected the amendment on the basis of security concerns:

It is difficult to see how most provisions respecting subversion and national security could be reconciled with the proposed amendment. No political party is illegal in Canada, yet membership in a particular party abroad, where it is probably legal is often the principle evidence that a person is a security risk. With the amendment it would appear that the subversion/security provisions could apply only in the case of an overt act defined as an offence in Canadian law. This would be going too far in the case of refugees. It would effectively prevent the screening out of people, although refugees by definition, who were forced to leave their countries of citizenship or residence because of their adherence to parties with extremist policies, which would be just as dangerous in Canada as elsewhere. ${ }^{69}$

The minister's objection to the amendments proves that the security mechanisms enacted toward refugees are essential and justified, and intimately connected to the government's political goals.

\section{Conclusion}

The study aims to shed light on how the Canadian government assembled its response to the Chilean refugee crisis in the first few months of the coup, and the conditions that made the Chilean refugee resettlement possible. It argues that despite the Canadian government's humanitarian claims, fear and (in)security framed and defined its approach to refugee protection. Such fear and (in)security gave rise to a complex nexus of power that shaped the Chilean refugee resettlement.

The study contributes to scholarly literature in three ways. First, it adds to a theory and methodology of practice in the field of refugee studies. It adopts the concept of apparatus/ assemblage to practice, and thus highlights the complexity involved in responding to refugee crises. By applying practices of assemblage, the article exposes how different forces and relations of power are assembled and reassembled to control the entry of refugees. It also shows how exclusion from protection is managed through the articulation and re-articulation of knowledge and power, and functions through the circulation of fear and anxiety. This understanding is pivotal in understanding how current refugee policies and practices are shaped.

Second, the article challenges the assumption that Canada's response to the Chilean refugees was influenced by the United States. My research found very little evidence to support this claim. Thus, the article contributes to new knowledge by emphasizing the Canadian government's independence in managing its response to this crisis.

Third, the article highlights the strengths and limitations of civil society in challenging government practices. The limited success of civil society in this resettlement points to the power of the security apparatus in deciding which lives are worth living. Yet it also underlines the potential of civil society to resist this apparatus. Civil society capitalized on public spaces, such as universities and churches, and exposed knowledge that the government had tried to conceal; it was therefore able to galvanize support and challenge government practices. However, since the 1970 s this public voice has been slowly institutionalized by being 
made a partner in decision-making. Hence government practices toward refugees have been presented as a compromise between competing public interests.

Future studies could explore further the tension between Canadian civil society and the security apparatus that seeks to impose the vision and desires of Canadian governing authorities. The question must be asked: Does this partnership hinder or facilitate refugee protection?

Suha Diab received her PhD in public policy and political economy from Carleton University in 2014. She is broadly interested in migration, security, and humanitarianism, especially policies and practices of inclusion/exclusion. The authormay be contacted at suhadiab@hotmail.com.

\section{Notes}

1 Joan Simalchik, "The Material Culture of Chilean Exile: A Transnational Dialogue," Refuge 23 (2006): 95-105.

2 George Hanff, "Decision Making under Pressure: A Study of the Admittance of Chilean Refugees to Canada," North/ South 6 (1979): 116-35.

3 See Gerald E. Dirks, Canada's Refugee Policy: Indifference or Opportunism? (Montreal and Kingston: McGillQueen's University Press, 1979); Harold Troper, "Canada's Immigration Policy since 1945," International Journal 48 (1993): 255-81; Reginald Whitaker, Double Standard: The Secret History of Canadian Immigration (Toronto: Lester \& Orpen Dennys, 1987).

4 See John F. Duggan, "Live Again in Community: Hispanic Refugees and the Church," Refuge 13 (1994): 19-25; also Valerie Knowles, Strangers at Our Gates: Canadian Immigration and Immigration Policy, 1540-1990, 3rd ed. (Toronto: Dundurn, 2007); Alan B. Simmons, "Latin American Migration to Canada: New Linkages in the Hemispheric Migration and Refugee Flow System," International Journal 48 (1993): 282-309.

5 Francis Peddie, Young, Well-Educated and Adaptable: Chilean Exiles in Ontario and Quebec, 1973-2010 (Winnipeg: University of Manitoba Press, 2014).

6 Ibid., 12.

7 Ibid.

8 "Recognition of the New Regime in Chile," memorandum to the minister, 27 September 1973, Political Affairs-Independence and Recognition-Chile, vol. 1, RG 25, Library and Archives Canada (LAC).

9 Mitchell Sharp, Which Reminds Me ... A Memoir (Toronto: University of Toronto Press, 1994), 172.

10 James F. Rochlin, Discovering the Americas: The Evolution of Canadian Foreign Policy towards Latin America (Vancouver: University of British Columbia Press, 1994).

11 On "cultural racism," see Etienne Balibar, "Is There a 'NeoRacism'?," in Race, Nation, Class: Ambiguous Identities, ed.
Etienne Balibar and Immanuel Maurice Wallerstein (London: Verso, 1991), 25-6.

12 Ross to External Affairs, "Special Operation," 11 December 1973, file 20-15-Chile-30-49, vol. 1, Political Affairs-Political Asylum, RG 25, LAC. See also Tanya Basok and Alan Simmons. "Refugees in Canada: A Review of the Politics of Refugee Selection," in Global Refugee Crisis: British and Canadian Responses, ed. V. Robinson, 132-57 (London: Oxford University Press, 1993).

13 Michel Foucault, Power/Knowledge: Selected Interviews and Other Writings, 1972-1977 (New York: Pantheon, 1980), 194.

14 Cited in Didier Bigo, "Globalized (in)Security: The Field and the Ban-Opticon," in Illiberal Practices in Liberal Regimes: The (In)Security Games, ed. Didier Bigo and Tsoukala Anastassia (New York: Routledge, 2006), 33.

15 Foucault, Power/Knowledge, 196.

16 Aihwa Ong, "Ecologies of Expertise: Assembling Flows, Managing Citizenship," in Global Assemblages: Technology, Politics and Ethics as Anthropological Problems, ed. Aihwa Ong and Stephen J. Collier (Oxford: Blackwell, 2004), 338 .

17 See Gilles Deleuze and Félix Guattari, A Thousand Plateaus: Capitalism and Schizophrenia, trans. Brian Massumi (Minneapolis, MN: University of Minnesota Press, 1987).

18 Mark B. Slater, "To Make Move and Let Stop: Mobility and the Assemblage of Circulation," Mobilities 8 (2013): 7-19.

19 Kevin D. Haggerty and Richard V. Ericson, "The Surveillant Assemblage," British Journal of Sociology 51 (2000): 605-22.

20 Slater, "To Make Move and Let Stop," 14.

21 Stephen Legg, "Assemblage/Apparatus: Using Deleuze and Foucault," Area 43 (2011): 129.

22 Tania M. Li, "Practices of Assemblage and Community Forest Management," Economy and Society 36 (2007): 264.

23 Colin McFarlane, "Assemblage and Critical Urban Praxis: Part One-Assemblage and Critical Urbanism," City 15 (2011): 204.

$24 \mathrm{Li}$, "Practices of Assemblage," 265.

25 Ann L. Stoler, Along the Archival Grain: Epistemic Anxieties and Colonial Common Sense (Princeton: Princeton University Press, 2009), 93.

$26 \mathrm{Li}$, "Practices of Assemblage," 265.

27 Nikolas Rose, Powers of Freedom: Reframing Political Thought (Cambridge: Cambridge University Press, 1999), 50.

$28 \mathrm{Li}$, "Practices of Assemblage," 266.

29 David D. Dewitt, and John J. Kirton, Canada as a Principal Power: A Study in Foreign Policy and International Relations (Toronto: John Wiley, 1983).

30 Peter C. Dobell, Canada's Search for New Roles: Foreign Policy in the Trudeau Era (Toronto: Oxford University Press, 1972), 49.

31 Rochlin, Discovering the Americas, 11. 
32 Cited in Brian J. Stevenson, Canada, Latin America, and the New Internationalism: A Foreign Policy Analysis, 19681999 (Montreal and Kingston: McGill-Queen's University Press, 2000), 192.

33 Ibid., 192-3.

34 Dobell, Canada's Search for New Roles, 49.

35 Sharp, Which Reminds Me, 172.

36 "Chile Report-Enterprise and Repression," MG28-I270-58, LAC.

37 "Summaries of Discussions at Meetings of the Board of Directors of IFC and the Executive Directors of the Bank and IDA," February 5 1974, World Bank Group-IBRD/IFC/ IDA-Relations with Member Countries-Chile, file 1-20, Volume 32, R200, LAC.

38 Ross described the killing in Chile as "abhorrent but understandable." See "Chile: Bloodletting," 20 September 1973, file 20-22-5-Chile-38-28, RG 25, LAC.

39 Ross to External Affairs, "Canada-Chile Relations," 1 November 1973, Telex, vol. 986, RG 76, LAC.

40 Ross also excelled on his yearly performance evaluation report until diplomatic exchanges between Ross and External Affairs were leaked to the media in November 1973. See A.D. Ross. Career. Employment Evaluations, 1972-1977, file 1, vol. 6, Chile, D-Mg 31 E 67, Ross, Andrew, LAC.

41 Several archival documents describe church group visits to meet the ambassador to Chile and other government officials in Ottawa, who were urged to resettle more Chileans.

42 This is not to say that Canadian civil society was unified in this response. Many letters to the editor expressed concern about this resettlement.

43 Michael Lavoie, "Canadian Envoy's Cables Say Killings in Chile 'Abhorrent But Understandable,"' Toronto Star, 6 November 1973.

$44 \mathrm{Li}$, "Practices of Assemblage," 271.

45 "Chile-Refuge," 25 October 1973, file 20-15-Chile, Political Affairs-Political Affairs-Political Asylums-Chile, RG 25, LAC.

46 "The Situation in Chile Reference to 'Refugees," 12 October 1973, Memorandum for the Minister, vol. 9409, Political Affairs-International Security-Coup D'etat-Chile, RG 25, LAC.

47 "Report on Visit to Chile," 24 November 1973, file 20-15Chile, Political Affairs-Political Affairs-Political Asylums-Chile, RG 25, LAC.

48 Stevenson, Canada, Latin America, and the New Internationalism, 130 .
49 "Memorandum to the Minister: Special Operation," 4 December 1973, vol. 9337, Political Affairs-Political Asylum-Chile, RG 25, LAC.

50 Ibid.

51 "Andras Says We Won't Admit Trouble-Making Chileans," Toronto Star, 3 December 1973.

52 "My Dear Prime Minister," 30 November 1973, file 20-15Chile, Political Affairs-Political Asylum-Chile, RG 25, LAC.

53 "Andras Says There Will Be Hell to Pay over Decision to Admit Chile Refugees," Toronto Star, 21 January 1974.

$54 \mathrm{Li}$, "Practices of Assemblage," 265.

55 Vivien A. Schmidt, "Discursive Institutionalism: The Explanatory Power of Ideas and Discourses," Annual Review of Political Science 11 (2008): 303-26.

56 Freda Hawkins, Canada and Immigration: Public Policy and Public Concern, 2nd ed. (Montreal and Kingston: McGill-Queen's University Press, 1988).

57 Giorgio Agamben, Means without End: Notes on Politics, trans. Vincenzo Binetti and Cesare Casarino (Minneapolis, MN: University of Minnesota Press, 200o), 42.

58 "Transcript of Interview by Brian Steward of СвC with Solicitor-General," 10 January 1974, vol. 9337, Political Affairs-Political Asylums-Chile, RG 25, LAC.

5926 December 1974, vol. 9337, Political Affairs-Political Asylum-Chile, RG 25, LAC.

60 Balibar, "Is There a 'Neo-Racism'?," 25-6.

61 Church groups quickly realized and contested this selection bias. In an interview with the a Toronto researcher for the United Church of Canada noted, "In dealing with the plight of refugees the government "has been hiding behind the applications from middle class people."' See "Churches Ask Sharp to Take Chileans," Toronto Star, 27 December 1973.

$62 \mathrm{Li}$, "Practices of Assemblage," 265.

63 Louis Parai, "Canada's Immigration Policy, 1962-74," International Migration Review 9 (1975): 449-77.

64 Hanff, "Decision Making under Pressure," 129.

65 Michael C. Lanphier, "Canada's Response to Refugees," International Migration Review 15 (1981): 198-211, 117.

66 James C. Hathaway, "Selective Concern: An Overview of Refugee Law in Canada," McGill Law Journal 33 (1988): 698.

67 Ibid.

68 Cited in Rhonda Howard, "Contemporary Canadian Refugee Policy: A Critical Assessment," Canadian Public Policy 6 (1980): 371.

69 Ibid. 


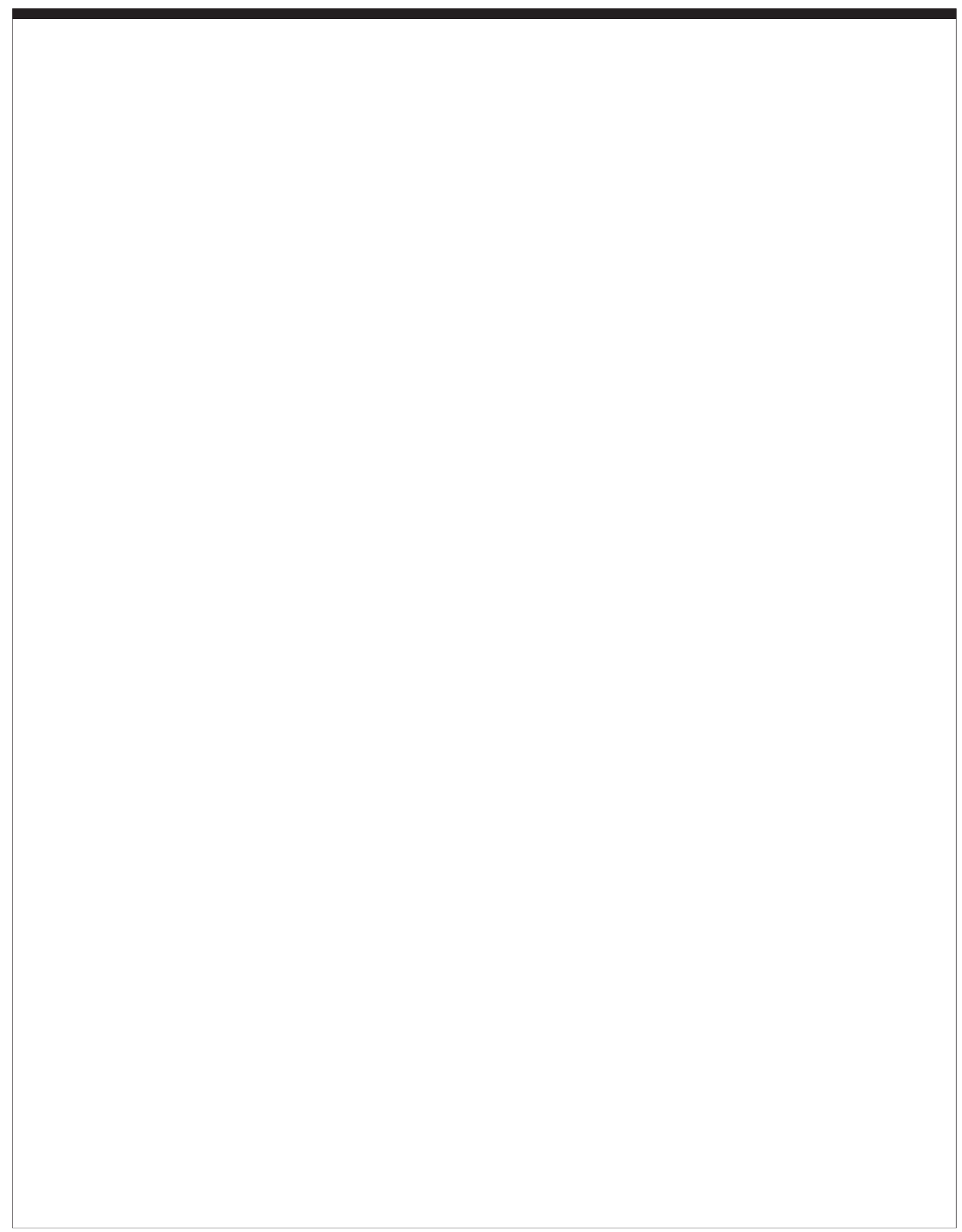

(C) Suha Diab, 2015. This open-access work is licensed under a Creative Commons Attribution-NonCommercial 4.0 International License, which permits use, reproduction and distribution in any medium for non-commercial purposes, provided the original author(s) are credited and the original publication in Refuge: Canada's Journal on Refugees is cited. 